DOI: $10.46640 / \mathrm{imr} .9 .17 .6$

UDK 794.02-028.23:2-455-042.3

Pregledni članak

Review article

Primljeno: 17.02.2020.

\title{
Iva Brěić
}

udruga Najsretnija beba Hrvatska, Zagreb najsretnijabeba@gmail.com

\section{Utjecaj video igara na djecu}

\section{Sažetak}

Video igre su postale glavni vid dječje zabave i način kako će djeca ispuniti svoje slobodno vrijeme. Više nisu samo povremena povlastica koju dijete dobije nakon što obavi svoje zadatke, već su postale sastauni dio svakodnevnog života. Postale su stalno dostupne na raznim igraćim konzolama, na kompjuterima, tabletima $i$ mobitelima. U Hrvatskoj gotovo $90 \%$ djece igra neku vrstu video igara. Uovom radu pažnja će biti usmjerena na razloge popularnosti video igara među djecom. Proučavat će se negativni utjecaji na dječje ponašanje, zdravlje i psihofizički razvoj. Također će se izučavati i pozitivna strana video igara i kako one mogu pridonijeti razvoju dječjih sposobnosti i pomoći u usvajanju brojnih znanja. $U$ radu će biti objašnjeno i na koji način se može poticati pozitivan utjecaj video igara, a kako umanjiti onaj negativan.

Ključne riječi: video igre, djeca, ovisnost o video igrama, negativni utjecaji video igara, pozitivni utjecaji video igara, virtualna socijalizacija. 


\section{Razlog velike popularnosti video igara kod djece}

Djeca žive u dva svijeta. Jedan je svijet odraslih, a drugi njihov svijet - svijet mašte. I dok im je prvi poprilično nejasan, čudan i pomalo dosadan sa svim silnim pravilima i zabranama, u dječjem svijetu sve je moguće. Pomoću mašte se stvaraju novi svjetovi i neobični likovi (recimo video igra Minecraft), postaje se super junacima, vrijede neka sasvim drukčija pravila, djeca sama stvaraju pravila, mogu nesputano učiti kroz igru i zabavu. Video igre su zapravo neka vrsta spoja tih dvaju svjetova koji zahvaljujući tehnološkim dostignućima nudi oživljavanje dječje mašte i omogućuje im da aktivno sudjeluju u njemu.

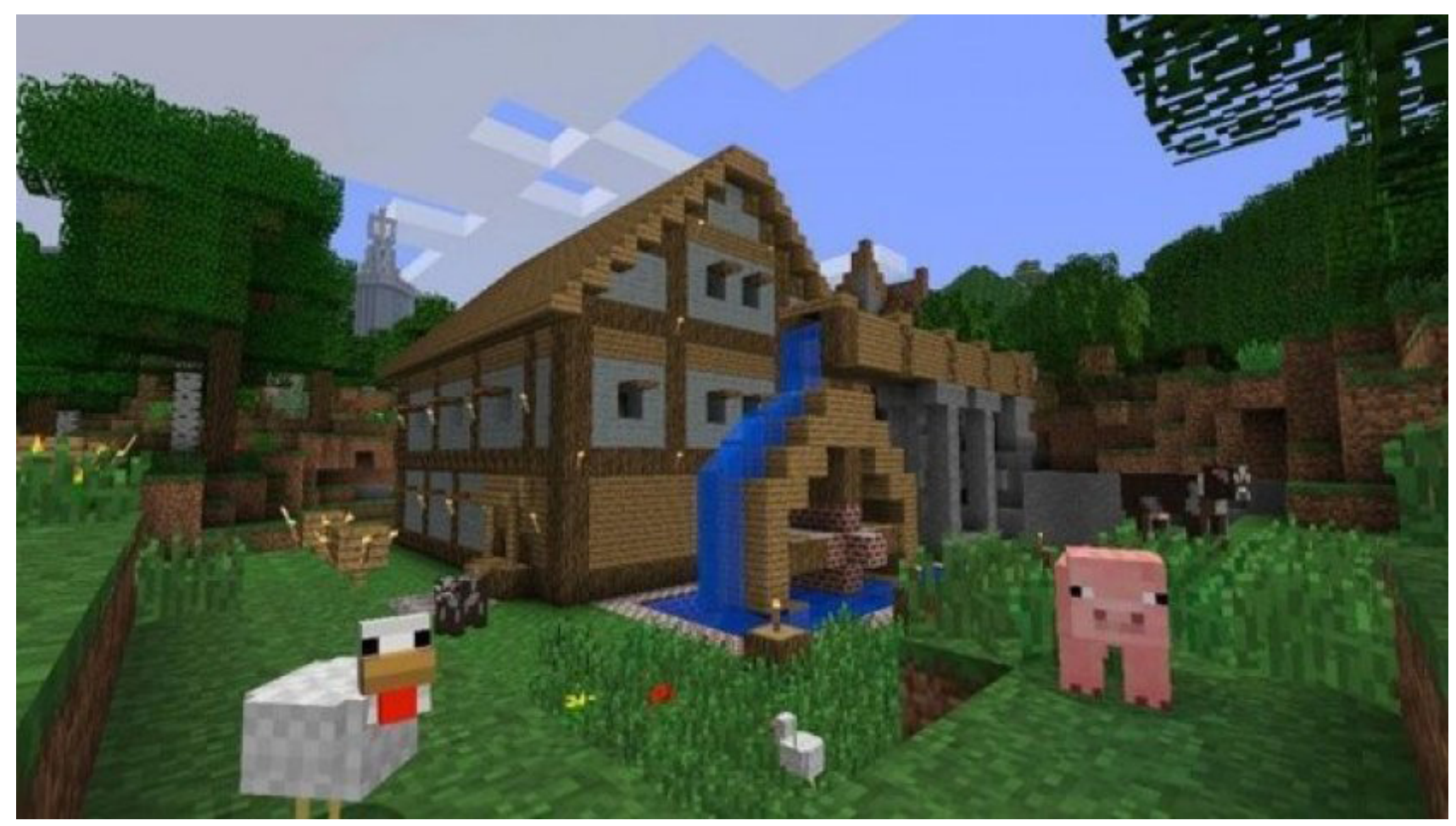

Minecraft - neobicni svijetovi

Likovi s kojima se lako povezati: Oni su obično antropomorfni s velikim očima i okruglastim licem. Zapravo imaju karakteristike lica bebe, a mi smo kao vrsta biološki predodređeni da sa simpatijama i radošću reagiramo na takva lica. Likovi su često i pojednostavljeni (imaju samo usta, nos i oči) is prenaglašenim dijelovima tijela (velika glava, veliki nos). Zapravo podsjećaju na likove koje djeca crtaju. Glavni junaci su često i životinje, a djeca vole životinje. Njihovo animiranje i davanje ljudskih osobina čini ih još privlačnijima i bliskijima.

Boje predstavljaju senzaciju svjetlosti, a svjetlost je energija. Energija pak može potaknuti, pobuditi, izazvati emocije, stvoriti osjećaje topline, hladnoće, udobnosti ili nelagode, a može utjecati i 
na fiziološka i psihološka ponašanja poput gladi ili agresije ${ }^{98}$. Da bi bolje razumjeli utjecaj boja u video igrama, potrebno se pozabaviti psihologijom boja. Jarke boje izazivaju snažnu, brzu i spontanu emotivnu reakciju, usmjeravaju pažnju i prenose subliminalne poruke. U video igrama se koriste za manipulaciju ponašanja i aktivaciju emocija, posebice, primarnih emocija. Zbog navedenog, kod osmišljavanja video igara posebna pažnja se pridodaje njihovom odabiru i kombinacijama. Uglavnom se koriste one koje su najzastupljenije u prirodi - crvena, žuta, plava, zelena, narančasta i ljubičasta, zatim one na koje najviše reagiramo, i one koje izazivaju slične ili iste reakcije kod većine ljudi u raznim kulturama - crvena, plava, žuta, zelena, ljubičasta, narančasta, ružičasta, siva, crna, bijela i smeđa. O njima ovisi ton video igre, te kakav će učinak imati na igrača. Tako na primjer, u video igri Crash Bandicoot skoro u svakoj sceni dominiraju jarka plava, crvena, narančasta i žuta boja koje pridonose osjećaju dinamike, napetosti i opasnosti.

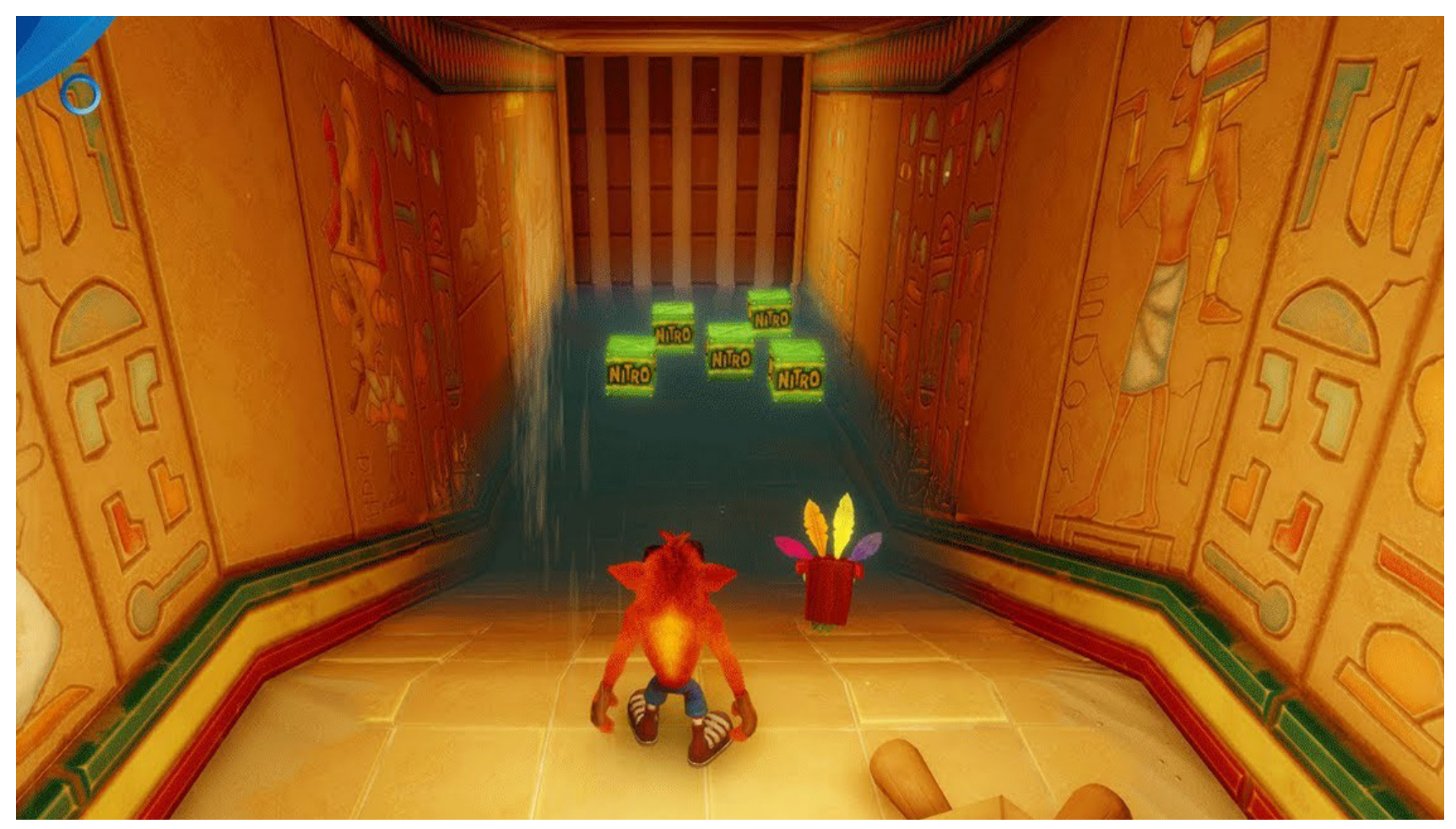

Crash Bandicoot - zivotinje u igrama, boje

98 DLI, Disruptedlogic interactive, https://disruptedlogic.com/2018/03/18/the-psychology-of-color-for-game-development/. 


\section{Psihološka svojstva boja}

\section{Crvena}

Pozitivna značenja: ljubav, snaga, energija, reakcija borbe ili bijega, uzbuđenje.

Negativna značenja: agresija, nasilje, naprezanje.

\section{Plava}

Pozitivna značenja: povjerenje, smiraj, učinkovitost, spokoj.

Negativna značenja: neprijateljstvo, hladnoća, bezosjećajnost.

\section{Žuta}

Pozitivna značenja: optimizam, samopoštovanje, kreativnost, prijateljstvo.

Negativna značenja: strah, depresija, tjeskoba, samoubojstvo.

\section{Zelena}

Pozitivna značenja: sklad, opuštanje, osvježenje, univerzalna ljubav.

Negativna značenja: dosada, stagnacija, slabljenje.

\section{Ljubičasta}

Pozitivna značenja: istina, kvaliteta, duhovna svijest, autentičnost

Negativna značenja: potiskivanje, inferiornost, dekadencija.

\section{Narančasta}

Pozitivna značenja: sigurnost, senzualnost, hrana, strast, zabava.

Negativna značenja: frustracija, nedostatak.

\section{Ružičasta}

Pozitivna značenja: ženstvenost, ljubav, seksualnost, preživljavanje vrste.

Negativna značenja: fizička slabost, inhibicija.

\section{Siva}

Pozitivna značenja: psihološka neutralnost.

Negativna značenja: nedostatak samopouzdanja, nedostatak energije.

\section{Crna}

Pozitivna značenja: glamur, sigurnost, učinkovitost.

Negativna značenja: nasilje, prijetnja, potlačenost. 


\section{Bijela}

Pozitivna značenja: čistoća, nevinost, sofisticiranost, učinkovitost.

Negativna značenja: barijere, hladnoća, elitizam, neprijateljstvo.

\section{Smeđa}

Pozitivna značenja: toplina, priroda, potpora, ozbiljnost.

Negativna značenja: nedostatak humora, nedostatak profinjenosti ${ }^{99}$.

U video igrama se forsiraju brze izmjene kadrova, montažne izmjene, promjene kuta kamere, zumiranja, te iznenadni zvukovi. Sve to potiče lučenje adrenalina koji u organizmu pokreće reakcije borbe ili bijega, te aktivira amigdalu, dio limbičkog sustava, koji je zadužen za prepoznavanje opasnosti i reakcije tijela. Dolazi do ubrzavanja rada srca, širenja krvnih žila koje šalju krv u mozak (mozgu je potrebno puno kisika i energije da napravi brze procjene situacije), sužavanja krvnih žila koje šalju krv u mišiće i dolazi do privremenog blokiranja alfa valova koji su zaduženi za opuštanje i spavanje. Nakon što je tijelo doživjelo ugodu ili uzbuđenje, aktiviraju se zrcalni neuroni koji oponašaju one radnje koje ce ponovo pridonijeti istom osjećaju.

Primarne emocije (radost, žalost, strah, gađenje, srdžba, iznenađenje) nastaju brzo i spontano, imaju univerzalnu facijalnu ekspresiju (otkrio Charles Darwin) i u različitim kulturama ih uzrokuju slični događaji. Na njih tijelo najjače reagira i njihov utjecaj se osjeti satima, danima, tjednima, pa čak i godinama. To to posebno vrijedi za strah. To je ujedno i jedan od razloga zašto se potiče nasilje u video igrama namijenjenim djeci, iako bi utjecaj na igrača trajao što duže i po završetku igranja. Za vrijeme igranja primarne emocije potiču i lučenje hormona endorfina i dopamina. Djelovanje endorfina je vrlo slično djelovanju recimo heroina, odnosno ublažava bol i pruža osjećaj ugode. On se luči u stresnim situacijama ili kada osjećamo iznimnu sreću. Endorfin je ključan za preživljavanje jer tijelu daje snagu i energiju kako bi pojedinac preživio u opasnim situacijama. Treba naglasiti da ljudski mozak ne razlikuje stvarnu opasnost od one koja je umjetno proizvedena i reagira na potpuno isti način. Hormon dopamin pak utječe na raspoloženje (pruža osjećaj sreće) i ponašanje. Jednom kada se počne lučiti, mozgu šalje signale zadovoljstva i uzbuđenja. On se smatra i hormonom ljubavi jer postoji mišljenje da zbog njega osoba postaje ovisna o onome koga voli. ${ }^{100}$ Upravo to su iskoristili tvorci video igara kako bi igre učinili što privlačnijima. Video igre potiču pojačano lučenje dopamina i s vremenom tijelo postaje ovisno o dobrom osjećaju koje mu one donose, te ih osoba želi opet igrati kako bi osjetila ugodu koju mu pružaju. Ovo je posebno izraženo kod djece jer ona nemaju potpuno razvijen sustav samokontrole i kontrole emocija i puno teže im se oduprijeti njihovim utjecajima.

99 Psychological Properties of Colours, http://www.colour-affects.co.uk/psychological-properties-of-colours.

100 Magazin,hr., Dopamin ima velik utjecaj na raspoloženje i izvršavanje obaveza, a možete ga naći u ovim namirnicama, https://net.hr/magazin/zdravlje/dopamin-ima-velik-utjecaj-na-raspolozenje-i-izvrsavanje-obaveza-a-mozete-ga-naciu-ovim-namirnicama. 
Perceptualno rješavanje problema je koncept prema kojem zadovoljstvo pruža i sam čin traženja, ne samo pronalazak predmeta ${ }^{101}$. Osim toga u video igrama se koristi operantno uvjetovanje, odnosno učenje na posljedicama. Psiholozi su otkrili da pojedinac nauči kako reagirati na određene podražaje ako ga se za to nagrađuje. Da bi potaknuli igrače na kontinuirano igranje, u video igre se uvodi raspored nagrada koje su vrlo poželjne, te pobuđuju daljnju želju za igrom ${ }^{102}$. U video igri, kada igrač ne uspije prijeći nivo zbog pogrešaka, ide ponovo pokušavajući ne ponoviti učinjene pogreške. Upravo taj put i uložen trud da se dođe do nagrade je ono što donosi zadovoljstvo.

U video igrama nema kritike niti bilo kakve klasifikacije. Razlike u spolu, dobi, rasi, te vjeri nisu bitne. Jedino što je važno je koliko se pridonosi zajedničkom cilju u video igri. Međutim, u svakodnevnom životu djeca se često osjećaju odbačenima, manje vrijednima ili nesposobnima zbog učestalih kritika roditelja, učitelja ili vršnjaka.

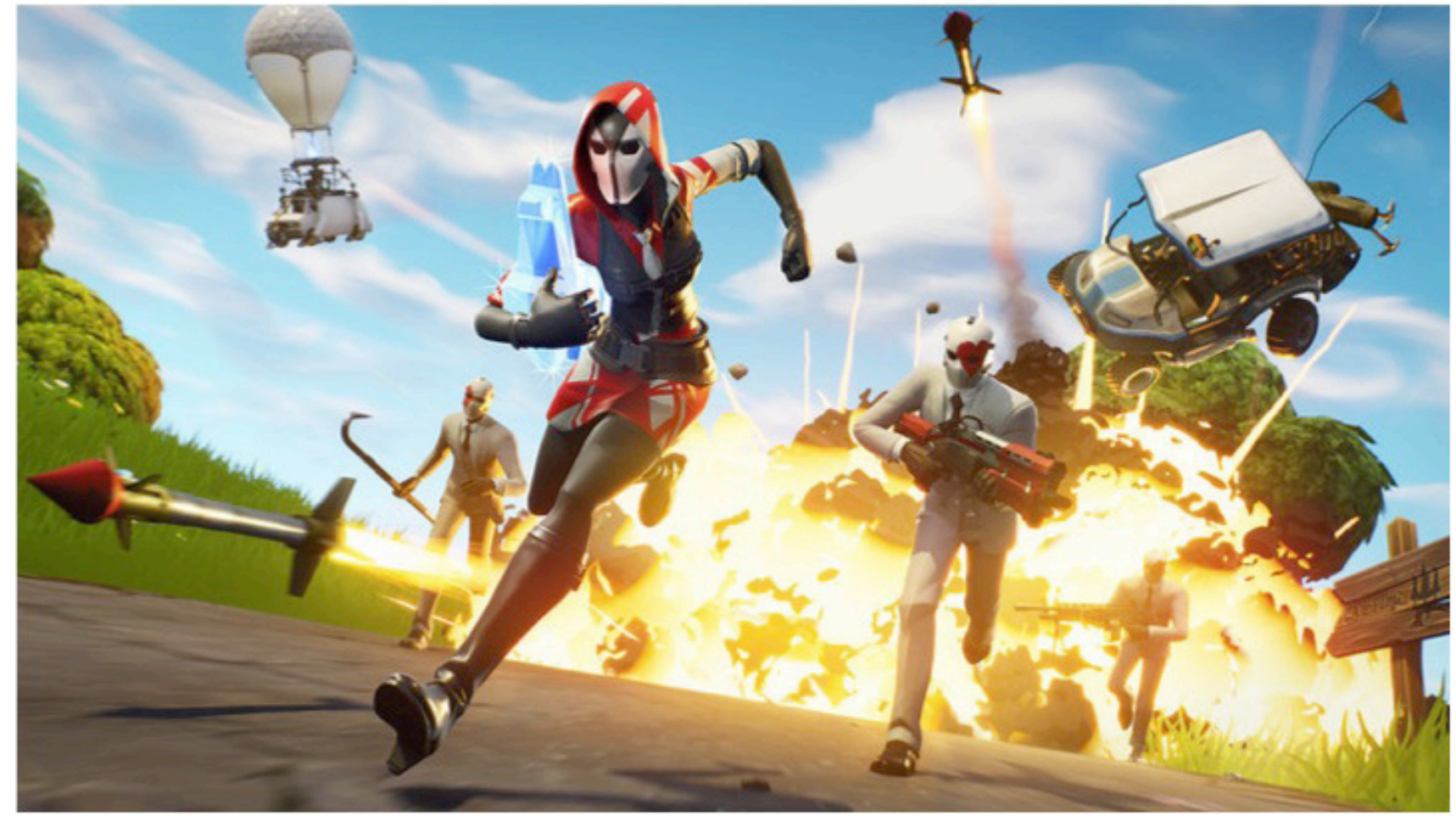

Fortnite - nasilje u video igrama

101 Vilayanur S. Ramachandran and Diane Rogers-Ramachandran, The Neurology of Aesthetics, SciAm Mind br. 5, 17 / 2004., str. 18.

102 Christine Yee, Behavior Principles and Good Game Design, http://yukaichou.com/gamification-study/behavior-principles-and-good-game-design/. 


\section{Razlozi igranja video igara}

John L. Sherry i Kristen Lucas ${ }^{103}$ su kroz svoja istraživanja otkrili šest glavnih motiva zbog kojih ljudi igraju videoigre. Prvi je natjecanje, s ciljem da igrač bude najbolji u igri. Zatim slijedi izazov, koji motivira igrača da dođe na sljedeću razinu ili pobijedi u igri. Veliku ulogu igra društvena interakcija, sa svrhom igranja s prijateljima i prikupljanja društvenog statusa. Nikako ne treba zaboraviti na razonodu, kako bi prošlo vrijeme ili se ublažila dosada. Zatim tu je maštanje, koje potiče igrača da u videoigri radi stvari koje u stvarnom životu ne može, te na kraju uzbuđenje i napetost ${ }^{104}$. Međutim, možda najvažniji motiv za igranje je uronjenost (engl. immersion) ${ }^{105}$ koji ima nekoliko značenja i razina. Prema istraživanjima, na prvoj razini, igraču se privlači pažnja (engl. engagement), na drugoj razini je zaokupljen igrom (engl. engrossment), a na trećoj je potpuno uronjen u virtualni svijet (engl. total immersion) ${ }^{106}$. Ovo je posebno važno kada se govori o djeci jer ona žive u mašti i uronjena su u svijet mašte iz dana u dan. Video igre im služe kao sredstvo da mogu u fizičkom svijetu doživjeti ono o čemu maštaju.

\section{Video igre u svakodnevnom životu djece}

Istraživanje percepcije djece o utjecaju videoigara ${ }^{107}$ koje je provedeno među 630 djece u dobi od 10 do 15 godina na području Grada Zagreba i Zagrebačke županije, pokazalo je da najveći broj djece igra svakodnevno (39,4 \%), nešto manji broj igra 2 do 3 puta u tjednu (31,2 \%), a samo vikendom najmanji broj $(29,4 \%)^{108}$. Kao što je i za očekivati, video igre najčešće igraju kod kuće. Polovina ispitanika video igre igra manje od jedan sat dnevno, iako se pokazalo da postoji i rizična skupina djece (4,5 \%) koji provode više od tri sata dnevno igrajući video igre. Kada se pak govori o svjetskoj statistici 66\% djece u dobi od 8 do 12 godina igra u prosjeku video igre dva sata dnevno. U dobi od 13 do 17 godina to se povećava na dva i pol sata dnevno ${ }^{109}$. Ono što je problematično je da veliki broj djece ne traži dopuštenje roditelja za igranje. Kroz rad s roditeljima sam uvidjela još nekoliko velikih problema, a to je da rijetko provjeravaju što dijete igra, da vremenski ne ograničavaju igranje i da ne nadziru djecu tijekom igranja video igara. Razlog tome leži u njihovom neznanju kako adekvatno ograničiti igranje video igara i pri tome izbjeći sukobe i svađe s djecom.

103 Kristen Lucas i John L. Sherry, Sex Differences in Video Game Play: A Communication - Based Explanatory, SAGE Publishing, Thousand Oaks, California 2004.

104 Danijel, Labaš, Ines Marinčić i Alma Mujčinović, Percepcija djece o utjecaju video igara Communication Management Review, Zagreb 2018., str. 10 - 11.

105 Danijel, Labaš, Ines Marinčić i Alma Mujčinović, Percepcija djece o utjecaju video igara, str. 11.

106 Ibid., str. 11.

107 Ibid., str., 10 - 11.

108 Dokler Ana, Istraživanje o videoigrama: navike, motivi i stavovi hrvatskih osnovnoškolaca, dostupno na https://www. medijskapismenost.hr/istrazivanje-o-videoigrama-navike-motivi-i-stavovi-hrvatskih-osnovnoskolaca/.

109 Center on media and Child's Health, https://cmch.tv/parents/video-games/. 
Naime, video igre su djeci postale iznimno važne i zbog njih će vrlo često prekršiti pravila, izbjegavati dužnosti i oglušiti se na zabrane. One im služe kao bijeg od svakodnevnih problema s kojima se susreću u školi u obitelji ili među vršnjacima. One su im odmor od brojnih obaveza i sredstvo za opuštanje. Djeci pružaju priliku da dobiju ono što im nedostaje u svakodnevnom životu. Prema dr. Edwardu Deciju i Richardu Ryanu djeca svakodnevno streme prema tome da budu što bolja u onome što rade, žele napredovati i žele uspjeti u onome što ih interesira. Također žele slobodu u odlučivanju kada se radi o onome što im je bitno. Iznimno im ja važna i povezanost s roditeljima i za tim žude. Međutim, sve to im je često uskraćeno ili vrlo ograničeno. Vrlo često se osjećaju sputano u svojim nastojanjima da istražuju i uče o svijetu u kojem žive. Igra i kreativno izražavanje im je ograničeno i svedeno na minimum. Žive konstantno pod stresom jer moraju slijediti brojna pravila i ispunjavati očekivanja svojih roditelja i zajednice.

\section{Negativni utjecaji video igara na djecu}

Istraživanje koje su proveli Sveučilište u Montrealu i institut Douglas pokazalo je da igranje akcijskih video igara utječe na razvoj mozga. Kod navedenih video igara igrač koristi navigacijsku strategiju "učenje odgovora" koja se temelji na stvaranju navigacijske "navike" i na nju se oslanja ${ }^{110}$. Upravo ta strategija je povezana sa smanjenjem sive tvari na području hipokampusa koji je zadužen za orijentaciju i epizodno pamćenje. Ova vrsta pamćenja je autobiografsko pamćenje koje dopušta pamćenje konkretnih činjenica ili osobnih iskustava ${ }^{111}$. Kod djece koja su ovisna o video igrama, koja učestalo i dugotrajno igraju igre može se razviti depresija. Kod njih dolazi do prestimuliranosti dopaminom, te nakon igranja često mogu biti mrzovoljna, tužna, lijena i nezainteresirana za stvari i događaje oko sebe jer im to ne pruža istu razinu stimulacije i osjećaj sreće. Može doći i do poremećaja pažnje, impulzivnosti, nedostatka samokontrole i kognitivne kontrole. Zbog velike količine podražaja, mozak biva prestimuliran i naprosto ne uspijeva odrediti koji su podražaji važni za razumijevanje situacija a koje može ignorirati.

U video igrama je veliki problem nasilje kojem su djeca izložena. Nakon što je tijelo doživjelo ugodu ili uzbuđenje, mozak i tijelo oponašaju one radnje koje će ponovo pridonijeti istom osjećaju. To je jedan od razloga zašto djeca nakon igranja igrica postaju nasilna ili hiperaktivna. Problem predstavlja i sterilizacija nasilja s minimalnim posljedicama ili se opravdava kao sredstvo da glavni junak dođe do cilja. Virtualni likovi postaju idoli koji se oponašaju bez obzira koliko njihovi postupci bili loši ili opasni. Prema dječjem načinu razmišljanja, oni su junaci koji uvijek čine ono što je ispravno i dobro. Djeca počinju usvajati nasilno ponašanje kao normalno. To s vremenom dovodi do gubitka

110 Maria Cohut, Action video games decrease gray matter, study finds, https:/www.medicalnewstoday.com/ articles/318839\#Action-games-effect-on-brain.

111 Sainte Anastasie, Psihologija, filozofija i razmišljanje o životu. Blog o filozofiji i psihologiji. Članci o različitim aspektima ljudske psihologije https://hr.sainte-anastasie.org/articles/psicologa/tipos-de-memoria-cmo-almacena-los-recuerdos-el-cerebro-humano.html. 
sposobnosti razlikovanja dobrog od lošeg ${ }^{112}$. Sve veći broj djece iskazuje smanjenu empatiju i brigu prema drugima. Treba ipak naglasiti da nasilne igre neće svu djecu pretvoriti u potencijalne ubojice niti će sva djeca zbog igara postati nasilnija, no vjerojatno će potaknuti agresivnost kod onih koji već imaju predispozicije za takvo ponašanje. Pritom su ranjivija ona djeca koja su manje uspješna u stvarnom životu i koja imaju niže samopoštovanje. Ona se u virtualnom svijetu osjećaju moćnije i uspješnije te ga zapravo žele projicirati na stvarnost.

No, to nije jedini problem. Veliki broj djece iskazuje probleme u socijalizaciji i komunikaciji. Zbog igranja video igara često gube prilike za razvoj socijalnih i komunikacijskih vještina kroz druženja i igru s drugom djecom u fizičkom svijetu. Zbog premalo kretanja djeca sve više imaju zdravstvenih problema poput pretilosti i dijabetesa.



Negativni utjecaj video igara

112 Iva Brčić, Utjecaj medija na gledatelja od najranije do odrasle dobi, Zbornik: Mediji kao središnji problem sadašnjosti, str. 235. 


\section{Pozitivni utjecaji video igara na djecu}

Video igre pružaju uvid u novi oblik socijalizacije, virtualnu socijalizaciju. Igre zahtijevaju racionalizaciju, sposobnost snalaženja i osiguravanje sredstava za preživljavanje. Igrači međusobno surađuju kako bi osmislili vlastite likove, stvorili vlastite ciljeve igre, te izgradili digitalne svjetove koji su za neke igrače ugodniji od življenja u stvarnom svijetu ${ }^{113}$. Virtualni svijet im pruža priliku za druženje i razmjenu iskustva. Igrači si međusobno pomažu i zajedno rješavaju probleme, a pri tome osobne karakteristike, nacionalna pripadnost, društveni status i sl. nemaju nikakav utjecaj. Istraživanje Elizabeth Behm - Moravitz je pokazalo da sve navedeno pridonosi povećanju empatije prema drugima, dijeljenja i pomaganja drugima i u stvarnom svijetu.

Djeca se uče i procjenjivati rizik, odnosno kako će njihovi postupci ili postupci drugih igrača utjecati na tijek događanja i suigrače. Djeca se uče kako raditi u timu, te kako voditi tim da bi se dostigao željeni cilj.

Video igre koje su sadržajem primjerene djetetovoj dobi mogu pridonijeti razvoju njegovih vještina i pomoći mu u usvajanju novih znanja; one djeci pružaju i vid zabave kroz koji mogu slobodno učiti i svladavati nove vještine. Djeca nisu sputana uputama trenera i učitelja ili željama roditelja, te imaju priliku učiti o stvarima koje im inače nisu dostupne (o svemiru, o Zemlji, o raznim narodima i kulturama...). Učenje kroz igru djeci je prirođeno i to je način kako uče i u stvarnom svijetu. Zbog toga video igre mogu imati veliki doprinos u učenju i usvajanju školskog gradiva.

Istraživanja su pokazala da video igre pridonose razvoju logičkog mišljenja, sposobnosti rješavanja problema, te poboljšavaju kritičko razmišljanje. Kod djece se razvija i bolja koordinacija oko - ruka, te preciznost. Video igre uvelike mogu pomoći u poboljšanju čitanja i učenju jezika, te računanja. Kod obavljanja zadataka i misija u video igri djeca se moraju dobro koncentrirati i vrlo dobro pamtiti što im je zadano i što se od njih zahtijeva. Također se razvija mapiranje i vizualna percepcija. Djeca moraju često pratiti mape, moraju se naučiti snalaziti u raznim okolinama i prostorima, te moraju obraćati pažnju na detalje. Svi ti izazovi i korištenje sposobnosti da bi se riješili problemi ili savladale prepreke kod djeteta utječe na povećanje samopouzdanja. Kada ono uspije svladati određenu prepreku javlja se osjećaj postignuća, a to pak pridonosi jačanju vjere u sebe. Dijete taj osjećaj onda preusmjerava i na druge sfere svog života. Ono razmišlja:"Ako sam mogao to učiniti, onda mogu i ovo."

Ono što nikako ne treba zaboraviti je da se dijete uči nositi i sa stresom. Naime, dok igra, suočava se s problemima koje ne može odmah riješiti, biva vraćeno unazad u igri, mora u kratkom vremenu naći rješenja i sl. Sve to mu pomaže da nauči kontrolirati svoje reakcije i kako umanjiti utjecaj stresa na njegove odluke i postupke.

113 Ibid., str. 234. 


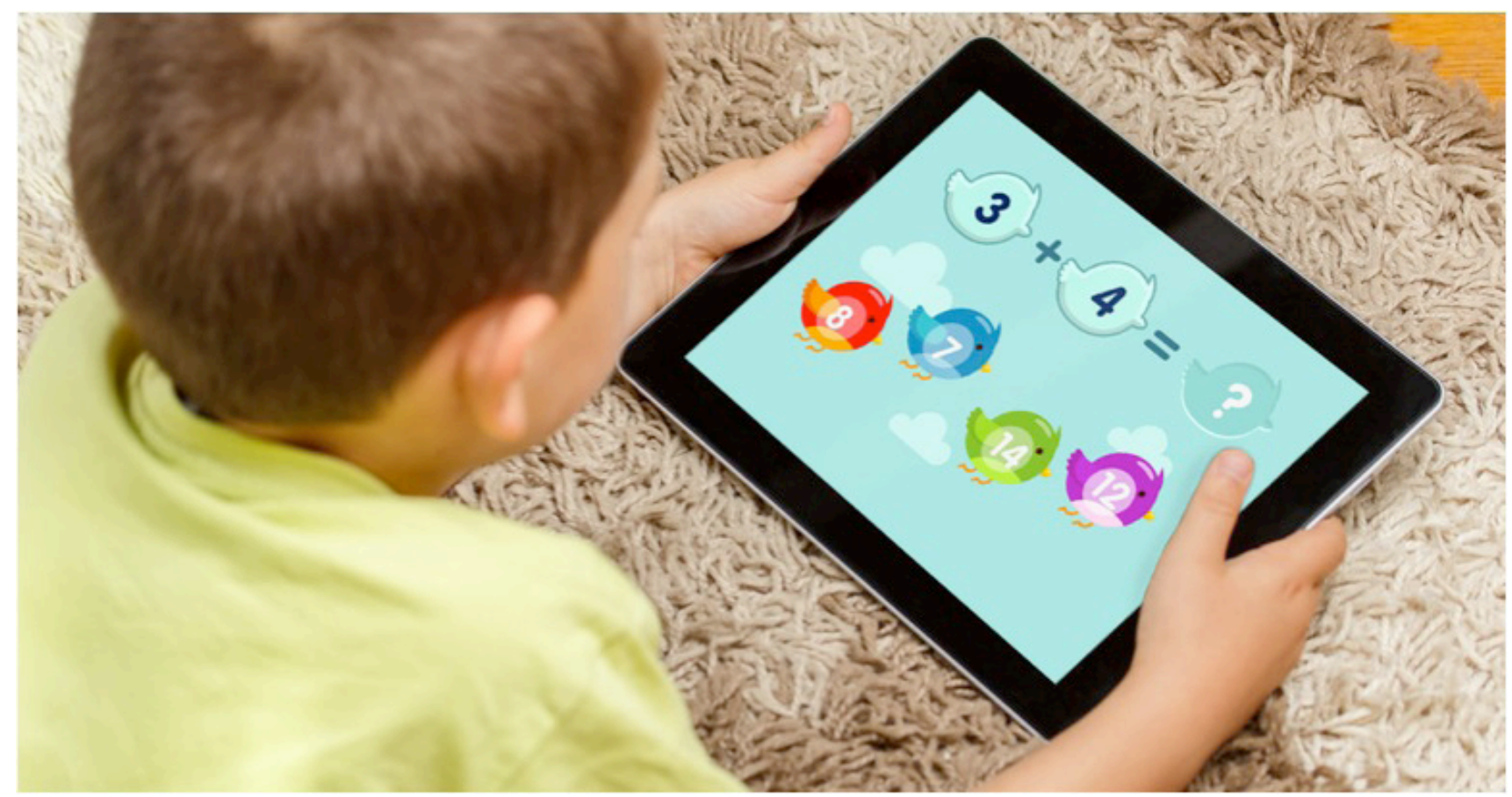

Pozitivan utjecaj video igara

\section{Poticanje pozitivnih učinaka video igara $i$ eliminiranje negativnih}

Da bi se potaknuli pozitivni učinci video igara i eliminirali negativni potrebno je prije svega da roditelji budu upoznati sa sadržajem video igara i da imaju nadzor nad djetetom. Ipak djeca igraju video igre najviše kod kuće. Ono što je ključno je da se roditelji pridržavaju ovih savjeta:

1. Odabrati video igre u skladu s dobi djeteta.

2. Vremenski ograničiti gledanje. Smanjenje vremena provedenog pred ekranom, dovodi i do smanjenja nasilnog ponašanja. Mnogi stručnjaci smatraju da je jedan sat dnevno vremenski okvir za igranje video igara. Međutim, prema mom iskustvu, rekla bih da je to previše jer već i za to vrijeme djeca postanu previše uronjena u video igru i teže im se isključiti. Moja preporuka bi bila oko 45 minuta, s tim da bih preporučila dane bez video igara.

3. Također bi bilo dobro da roditelji prvo pogledaju najavu za video igru, provjere sadržaj i pročitaju recenzije. Tako se mogu najbolje uvjeriti je li video igra primjerena za dijete.

4. Ako dođe do nasilja trebaju s djetetom razgovarati o tome što je uzrokovalo takvo ponašanje, te dati do znanja da se problemi ne rješavaju na taj način. Također mogu pitati dijete kako bi se problem mogao riješiti bez nasilja.

5. Usmjeriti im pažnju na sadržaj koji pridonosi razvoju kreativnosti, potiče znatiželju, empatiju, suradnju i pomaganje. 


\section{Popis video igara}

Super Mario Odyssey 3+ - avantura kroz razne dijelove svijeta

Yoshi's Crafted World 3+ - istraživanje

LittleBigPlanet 3 + - rješavanje problema i kreiranje igre

Scribblenauts: Showdown $5^{+}-$rješavanje problema

The Magic school bus $5^{+}$- istraživanje

Mario Kart 8 Deluxe 6 + - vožnja

LEGO 6 + - kreiranje

Snipperclips $8+$ - rješavanje problema

Rocket League 8 + - vožnja, vježbanje gađanja loptom

Unravel 28 + - rješavanje problema i zagonetki

Yooka-Laylee 9+ - rješavanje zagonetki, borba protiv negativaca

Overcooked 2 10+ - kuhanje

No Man's Sky 10 + - izučavanje planeta, biljaka, minerala

Splatoon $210+$-vježbe gađanja ${ }^{114}$

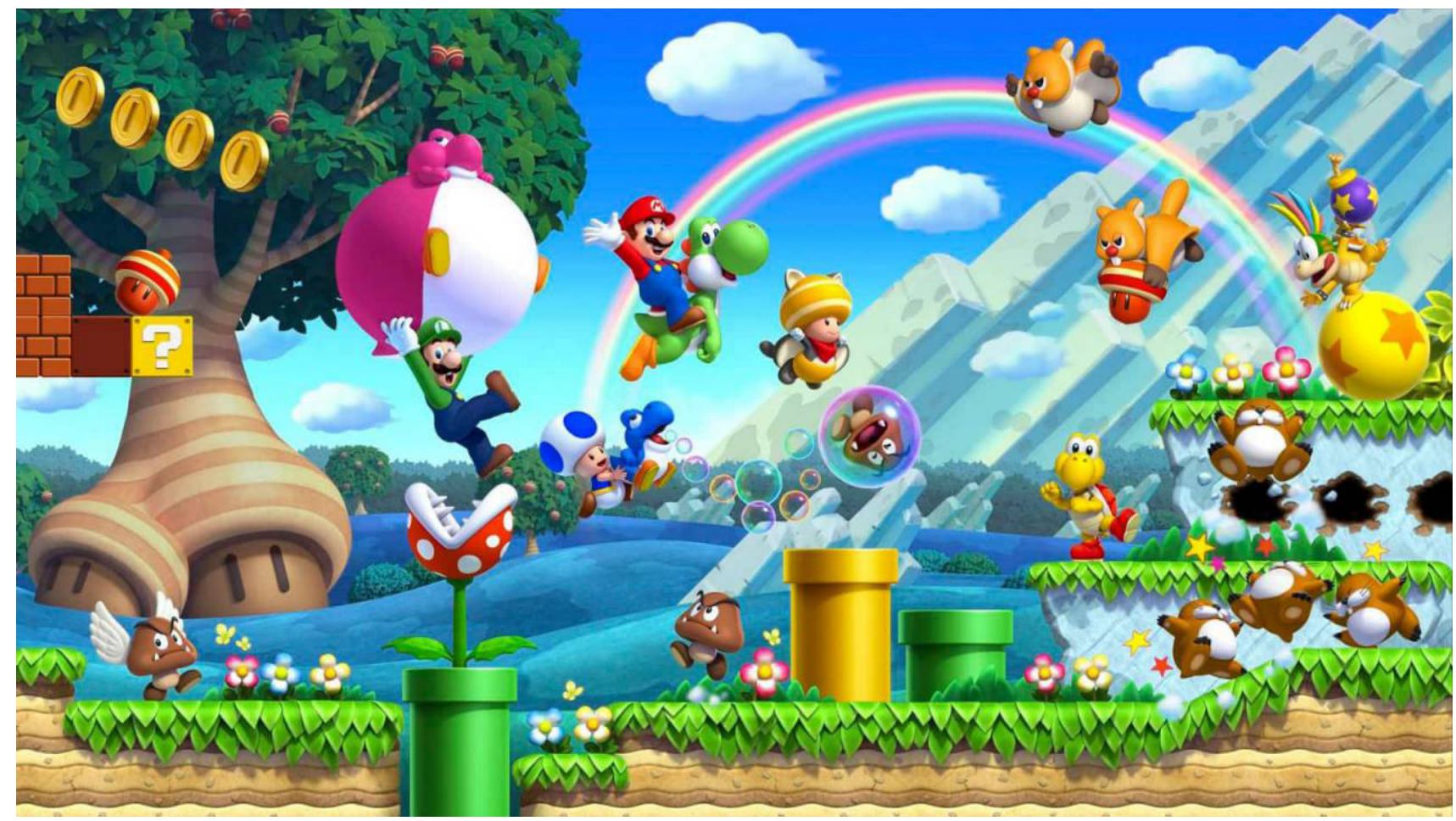

Super Mario - zabava

114 Comon Sense Media, Game riviews, https://www.commonsensemedia.org/game-reviews. 


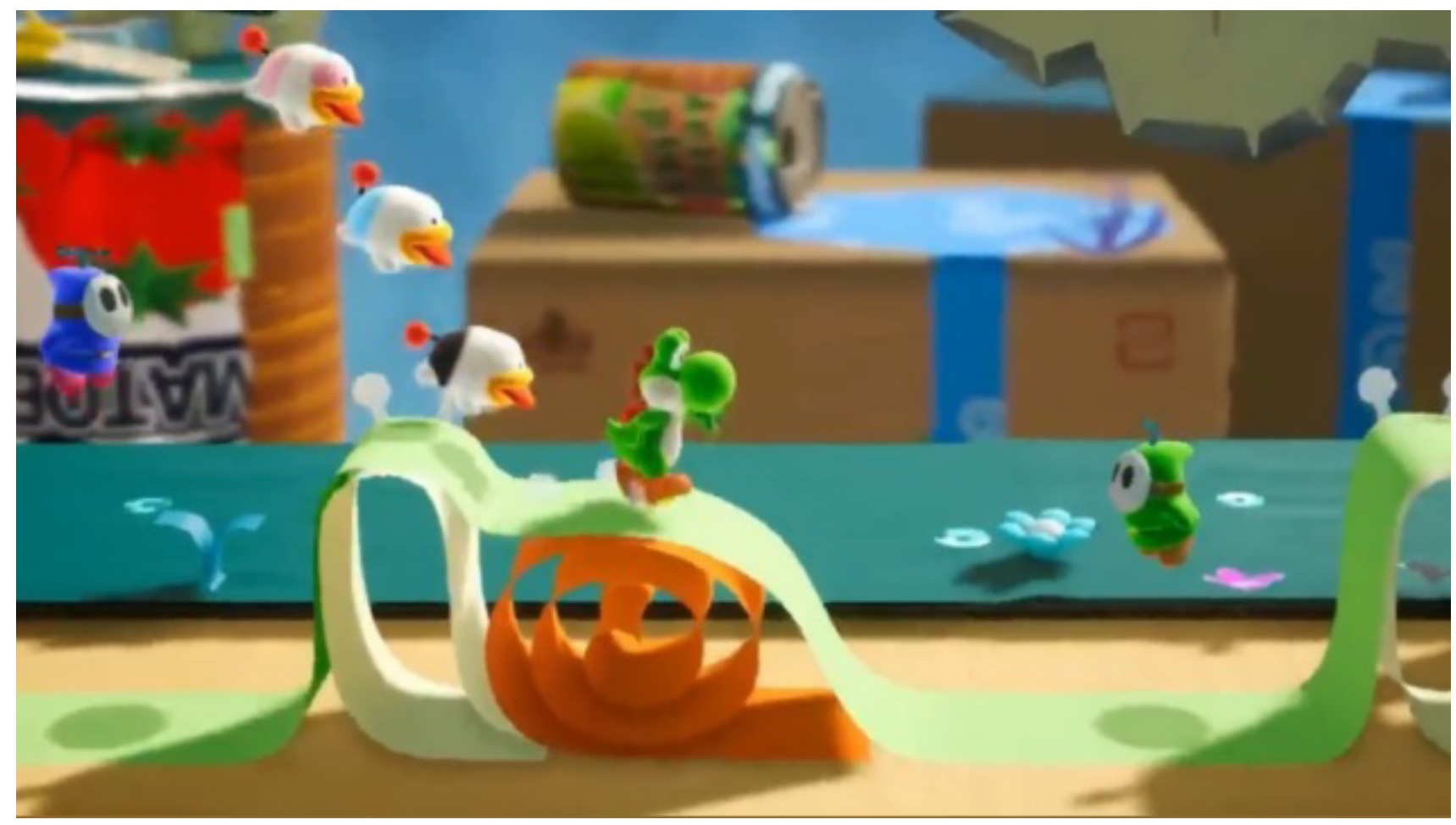

Yoshi's Crafted World - zivotinje u igrama, neobicni likovi

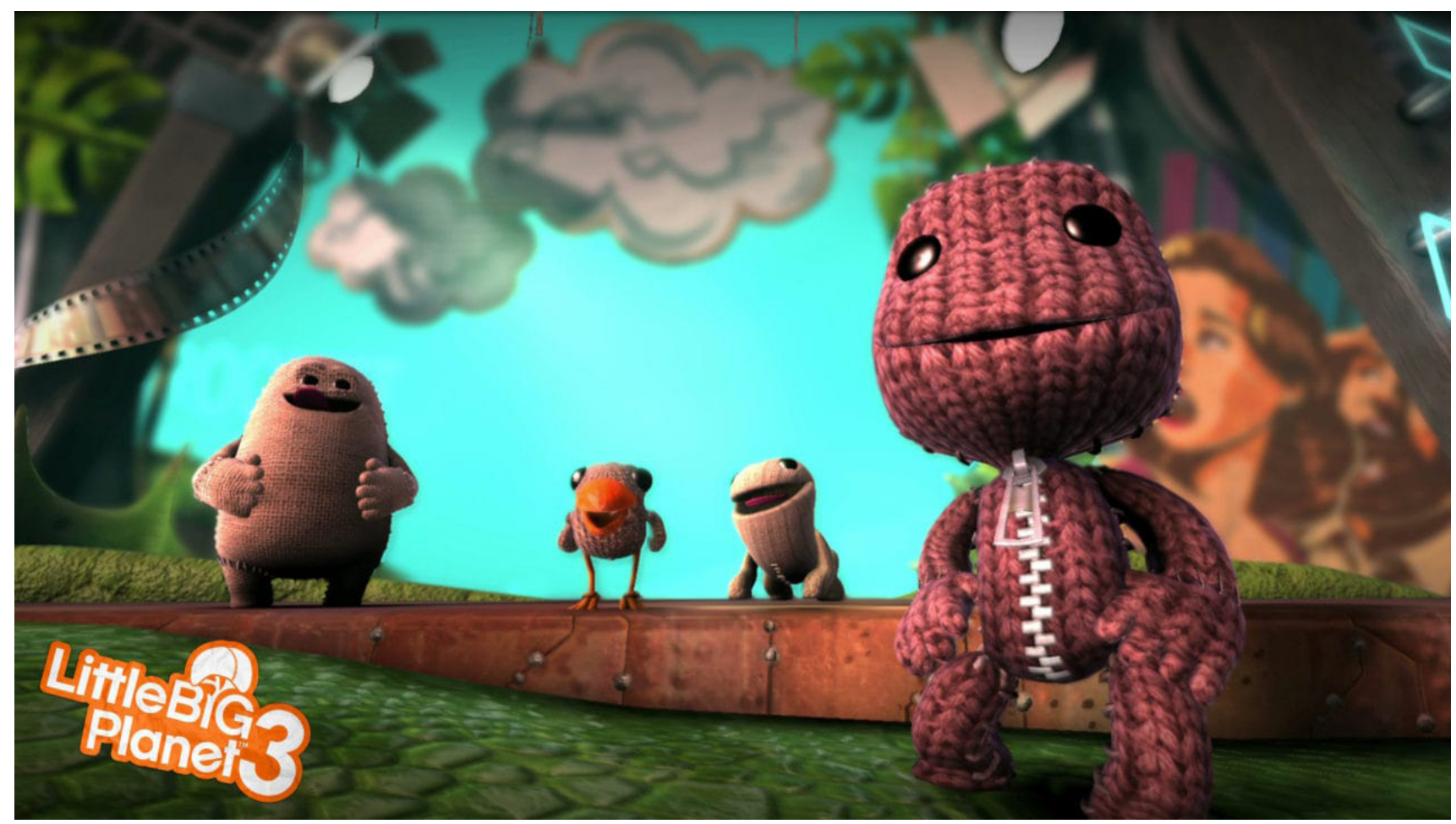

LittleBigPlanet neobicni likovi 


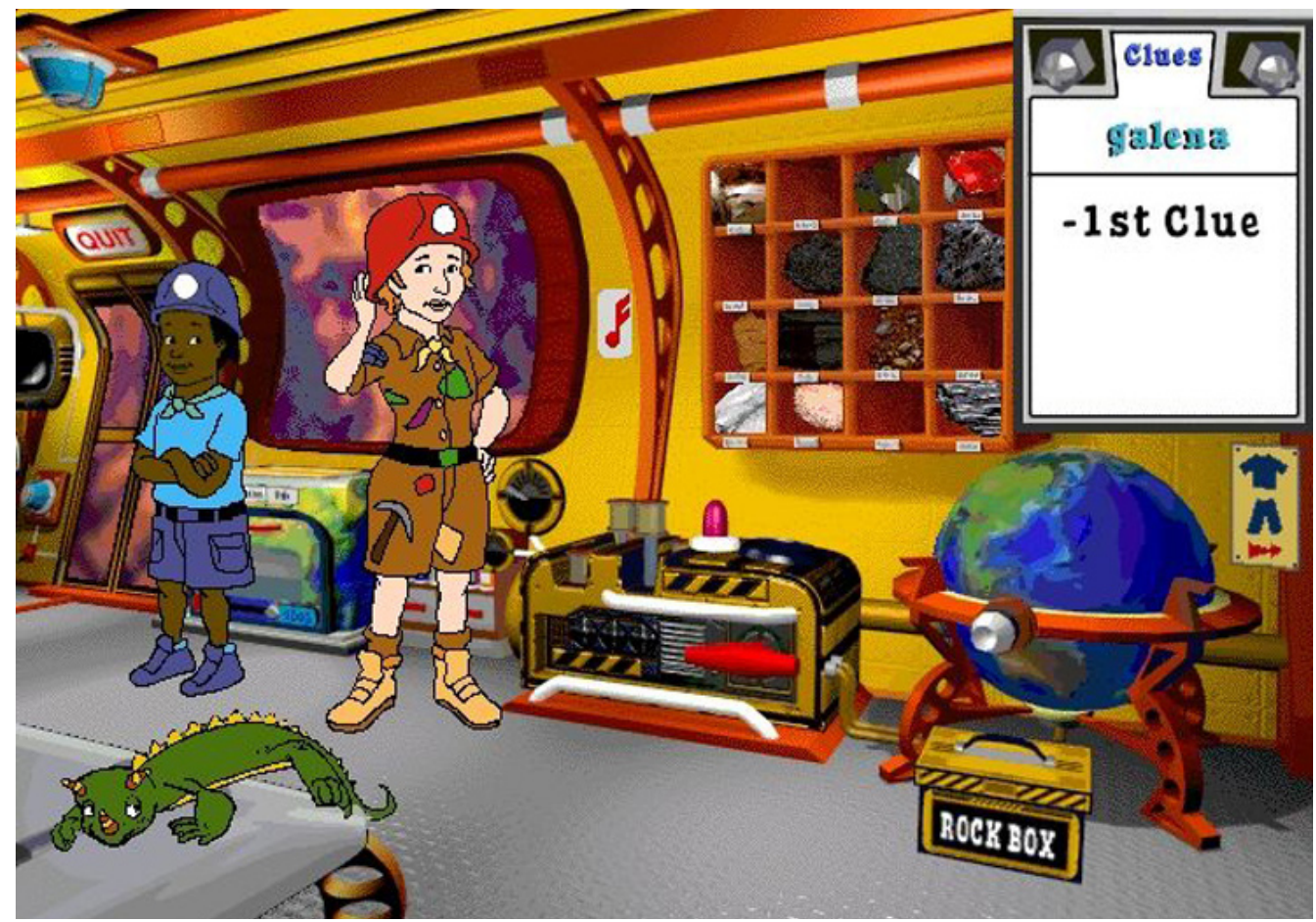

The Magic school bus - edukacija

\section{Zaključak}

Živimo u svijetu u kojem je igranje video igara nemoguće zabraniti. Zabrana igranja nikad nije rješenje i često rezultira sukobom između roditelja i djece, te otuđenjem djece. Umjesto toga treba shvatiti da su video igre danas dio ljudske svakodnevice te s djecom o njima treba razgovarati i educirati ih. Djeci treba pružati stvarne doživljaje i iskustva koja će im pružiti zadovoljstvo i zabavu. Roditelji se trebaju više usmjeriti na svoju djecu i svakodnevno im pružati pažnju, ljubav i pohvale za njihova djela. Upravo je to ono što djeca od njih traže a ne dobivaju, te zbog toga bježe u virtualni svijet video igara. Treba reći da video igre nisu ni dobre ni loše. Kakav utjecaj imaju na djecu ovisi o tome kako ih svi mi koristimo, pogotovo roditelji. Naime mnogi roditelji iskazuju simptome ovisnosti o malim ekranima i video igrama. Djeca uče po modelu i naprosto oponašaju njihovo ponašanje i usvajaju ga kao normalno.

\section{Literatura:}

Brčić Iva, Utjecaj medija na gledatelja od najranije do odrasle dobi, Zbornik: Mediji kao središnji problem sadašnjosti, In medias res: časopis filozofije medija, vol. 7 No. 13, 2018., str. 234 235 .

Cohut, Maria, Action video games decrease gray matter, study finds, dostupno na https://www. medicalnewstoday.com/articles/318839\#Action-games-effect-on-brain, 2017., preuzeto 14 . veljače. 2020. 
Dokler Ana, Istraživanje o videoigrama: navike, motivi i stavovi hrvatskih osnovnoškolaca, dostupno na https://www.medijskapismenost.hr/istrazivanje-o-videoigrama-navikemotivi-i-stavovi-hrvatskih-osnovnoskolaca/ 2019., preuzeto 5. veljače 2020.

Labaš, Danijel, Marinčić, Ines i Mujčinović Alma, Percepcija djece o utjecaju video igara Communication Management Review, Zagreb 2018., str. 10 - 11.

Lucas, Kristen i Sherry, John.,L., Sex Differences in Video Game Play: A Communication - Based Explanatory, SAGE Publishing, Thousand Oaks, California 2004.

Vilayanur S. Ramachandran, Vilyanur, S. i Rogers, Ramachandran, Diane, The Neurology of Aesthetics, SciAm Mind 517 / 2004., str. 18.

Yee, Christine, Behavior Principles and Good Game Design, dostupno na http://yukaichou. com/gamification-study/behavior-principles-and-good-game-design/ 2015., preuzeto 5. veljače 2020 .

\section{Ostali izvori:}

Center on Media and Child's Health, https://cmch.tv/parents/video-games/, preuzeto 7. veljače 2020.

Comon Sense Media, Game riviews, https://www.commonsensemedia.org/game-reviews, preuzeto 15. veljače 2020.

DLI, Disruptedlogic interactive, https://disruptedlogic.com/2018/03/18/the-psychology-ofcolor-for-game-development/, preuzeto 5. veljače 2020.

Magazin,hr., Dopamin ima velik utjecaj na raspoloženje i izvršavanje obaveza, a možete ga naći u ovim namirnicama, https://net.hr/magazin/zdravlje/dopamin-ima-velik-utjecaj-naraspolozenje-i-izvrsavanje-obaveza-a-mozete-ga-naci-u-ovim-namirnicama/, preuzeto 5 . veljače 2020.

Parents, https://www.parents.com/toddlers-preschoolers/everything-kids/whoa-when-it-comesto-video-games-an-hour-a-day-is-ok/, preuzeto 15. veljače, 2020.

Sainte Anastasie, Psihologïja, filozofija i razmišljanje o životu. Blog o filozofiji i psihologiji. Članci o različitim aspektima ljudske psihologïje. https://hr.sainte-anastasie.org/articles/ psicologa/tipos-de-memoria-cmo-almacena-los-recuerdos-el-cerebro-humano.html, preuzeto 7. veljače 2020 . 


\section{Effects of Video Games on Children}

\section{Sažetak}

Video games have become the most important aspect of entertainment for children and the way how they spend their free time. Video games aren't a privilege that children have after they do their chores anymore. They are a part of children's everyday life. They can be played on gaming consoles, on computers, tablets, and smartphones. Almost 9o\% of children in Croatia play some kind of video game. This paper will focus on the reasons for the popularity of video games among children. Negative influences on children's behavior, health, and psychophysical development will be studied. The positive side of video games will also be explored and how they can contribute to the development of children's skills and help them acquire knowledge. The paper will explain how the positive impact of video games can be encouraged and how to reduce the negative ones.

Ključne riječi: video games, children, video game addiction, negative effects of video games, pozitive effects of video games, virtual socialization.

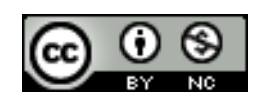

This journal is open access and this work is licensed under a Creative Commons Attribution-NonCommercial 4.0 International License. 